\title{
PEMBERDAYAAN MOTIVASI SISWA SMP AL-INAYAH KECAMATAN PURWOSARI KABUPATEN PASURUAN MELALUI PELATIHAN ESQ (EMOTIONAL AND SPIRITUAL QUOTIENT)
}

\author{
Dwi Candra Setiawan ${ }^{1 *}$, Primadya Anantyarta ${ }^{2}$, Nila Kartika Sari ${ }^{3}$ \\ 1,2,3Program Studi Pendidikan Biologi IKIP Budi Utomo Malang, Indonesia \\ dwicandrasetiawan@budiutomomalang.ac.id, primadyaanantyarta@budiutomomalang.ac.id
}

\begin{abstract}
ABSTRAK
Abstrak: Kemampuan peserta didik tidak hanya dapat diberdayakan melalui proses belajar saja. Pelatihan Motivasi merupakan salah satu cara yang dapat ditempuh oleh pendidik untuk mampu memberdayakan kemampuan yang dimiliki peserta didiknya. Adanya peningkatan motivasi yang dimiliki oleh peserta didik secara tidak langsung dapat mempengaruhi proses belajar, sehingga kemampuan peserta didik juga akan berkembang. Pengabdian masyarakat ini bertujuan untuk meningkatkan motivasi belajar siswa Siswa SMP Al-Inayah Kecamatan Purwosari Kabupaten Pasuruan. Target khusus pada program pelatihan motivasi dan ESQ ini adalah siswa dapat lulus Ujian Nasional seiring dengan meningkatnya motivasi belajar siswa. Kegiatan dalam program ini meliputi: persiapan dengan mengadakan observasi lokasi, wawancara dengan Kepala Sekolah dan siswa, pengajuan ijin pelaksanaan pelatihan, persiapan sarana dan prasarana pelatihan, pelaksanaan pelatihan, refleksi pelaksanaan pelatihan dan pembuatan laporan akhir pengabdian.
\end{abstract}

Kata Kunci: Pelatihan, Motivasi, ESQ.

Abstract: The ability of students can not only be empowered through the learning process. Motivation Training is one way that educators can take to be able to empower the abilities of their students. An increase in motivation possessed by students can indirectly affect the learning process, so the ability of students will also develop. This community service aims to increase student motivation in Al-Inayah Junior High School Purwosari District, Pasuruan Regency. The specific target of the motivation and ESQ training program is students can pass the National Examination along with the increase in student motivation. Activities in this program include: preparation by conducting site observations, interviews with principals and students, submitting licenses for conducting training, preparing training facilities and infrastructure, conducting training, reflecting on the implementation of training and making a final report.

Keywords: Training, Motivation, ESQ

\section{A. LATAR BELAKANG}

Kecamatan Purwosari merupakan salah satu kecamatan yang berada di Kabupaten Pasuruan Jawa Timur. Purwosari merupakan salah satu kecamatan yang berbatasan langsung dengan Malang setelah Kecamatan Purwodadi. Peningkatan hasil belajar siswa merupakan salah satu tujuan yang ingin dicapai oleh para pendidik (Kemenristekdikti, 2015). Peningakatan hasil belajar merupakan salah satu indikator yang dapat digunakan oleh para pendidik untuk mengetahui keberhasilan dalam proses pembelajaran yang sudah dijalankan (Arifin \& Rahmawati, 2012). Untuk meningkatakan hasil belajar tersebut banyak cara dan upaya yang dilakukan oleh para pendidik, salah satunya dengan melakukan variasi, 
inovasi dalam proses pembelajaran dengan menggunakan model-model pembelajaran (Suryanti, 2016).

Peningkatan hasil belajar siswa tidak hanya dapat ditingkatkan hanya dengan melakukan inovasi dalam pembelajaran, akan tetapi siswa juga mampu meningkatkan hasil belajarnya jika motivasi belajar siswa juga tinggi. Hal ini dikarenakan siswa yang memiliki motivasi kuat, akan mempunyai banyak energi untuk melakukan kegiatan belajar (Nurhidayah, 2015). Selain itu motivasi juga dapat berfungsi mendorong timbulnya suatu kelakuan atau suatu perbuatan, sebagai pengarah (Erwinsyah, 2017). Oleh karena itu sebagai seorang guru sangat penting pula untuk meningkatkan motivasi belajar siswa agar siswa punya gairah dan semangat yang tinggi dalam belajar. Upaya peningkatan motivasi siswa dapat dilakukan dengan berbagai upaya salah satunya adalah melalui pelatihan motivasi (Mendari \& Kewal, 2016).

Pelatihan motivasi diberikan bertujuan untuk membangkitkan atau meningkatkan motivasi seseorang. Pelatihan motivasi ini salah satunya adalah ESQ. Pelatihan ESQ atau yang lebih sering disebut training ESQ merupakan suatu metode yang menggabungkan tiga aspek kecerdasan IQ, EQ dan SQ dengan sebuah pelatihan untuk melatih seseoarang supaya mampu menjadi manusia yang mempunyai mental, karakter yang kuat dan positif (Zainal Arifin, 2015). Pelatihan seperti ini memang sangat jarang dilakukan oleh sekolah-sekolah yang terdapat di Indonesia, salah satunya yaitu sekolah yang dijadikan mitra dalam pengabdian ini yaitu SMP AlInayah Kecamatan Purwosari Kabupaten Pasuruan. Hal ini dikarenakan salah satunya adalah biaya yang cukup mahal untuk mengadakan pelatihan motivasi. Bahkan berdasarkan hasil wawancara dengan salah satu guru menjelaskan bahwa pelatihan motivasi seperti ESQ tidak pernah dilakukan selama ini. Selain itu pula berdasarkan hasil pengamatan dan wawancara dengan anak-anak sekitar tempat tinggal terlihat motivasi belajar siswa sangat kuarang. Para siswa menjalankan rutinitas sekolah hanya sekedar untuk lulus dan memenuhi permintaan orang tua mereka tanpa ada motivasi untuk apa mereka belajar.

Berdasrkan penjelasan di atas maka dilakukannya pengabdian masyarakat dengan judul Pemberdayaan Motivasi Siswa SMP Al-Inayah Kecamatan Purwosari Kabupaten Pasuruan Melalui Pelatihan ESQ (Emotional And Spiritual Quotient).

\section{B. METODE PELAKSANAAN}

Tahap pertama, melakukan kegiatan observasi terhadap tempat yang akan dilakukan pelatihan yaitu SMP Islam Al-Inayah Purwosari. Pada Tahap pertama yang dilakukan adalah melakukan observasi yaitu dengan melakukan wawancara kepada kepala sekolah dan juga beberapa siswa serta guru. Wawancara ini dilakukan untuk mengetahui apakah kegiatan pelatihan seperti ESQ pernah dilakukan dan juga untuk mengetahui hasil belajar siswa. Tahap kedua, pelaksanaan pelatihan motivasi ESQ. Pada tahap kedua ini dilakukan dengan dua sesi. Dimana sesi pertama diisi dengan pemberian materi ESQ dan untuk sesi kedua merupakan sesi penancapan dari hasil pemberian sesi pertama. Tahap ketiga, analisis dan pelaporan hasil pelatihan. 


\section{HASIL DAN PEMBAHASAN}

\section{Persiapan dengan mengadakan observasi lokasi}

Persiapan dengan mengadakan observasi lokasi dilakukan pada hari Senin, 22 Februari 2016 oleh tim pengabdian di SMP Al-Inayah Kecamatan Purwosari Kabupaten Pasuruan. Kegiatan ini dilakukan untuk mengetahui kondisi lingkungan sekolah dan tingkat motivasi siswa dalam proses pembelajaran khususnya dalam menyongsong ujian akhir nasional.

Secara garis besar motivasi belajar yang dimiliki oleh siswa siswi SMP Al-Inayah Kecamatan Purwosari Kabupaten Pasuruan, termasuk dalam katagori yang masih rendah. Hal ini ditunjukkan dengan selama proses pembelajaran berlangsung, terdapat beberapa siswa yang ramai, mengantuk, senang bermain sendiri serta tidak semangat dalam mengikuti materi pembelajaran.

\section{Wawancara dengan Kepala Sekolah dan siswa}

Berdasarkan hasil wawancara dengan kepala SMP Al-Inayah Kecamatan Purwosari Kabupaten Pasuruan, didapatkan informasi mengenai kondisi dan situasi pembelajaran sudah berlangsung dengan baik, namun kurang kondusif dan maksimal. Terlebih siswa-siswi akan menghadapi ujian akhir nasional yang menentukan nilai kelulusan mereka. Bapak ibu guru SMP Al-Inayah Kecamatan Purwosari Kabupaten Pasuruan, telah mengajar dengan baik tetapi masih merasa khawatir akan motivasi siswa-siswi yang cenderung menurun dan menggampangkan ujian akhir nasional.

Harapan dari kepala sekolah, dengan adanya pelatihan ESQ untuk siswa-siswi SMP Al-Inayah Kecamatan Purwosari Kabupaten Pasuruan adalah dapat meningkatkan motivasi belajar untuk mempersiapkan diri dalam menghadapi ujian akhir nasional dan hasil belajar yang diharapkan meningkat.

\section{Pengajuan ijin pelaksanaan pelatihan}

Sebelum memulai pelaksanaan pengabdian pelatihan ESQ di SMP AlInayah Kecamatan Purwosari Kabupaten Pasuruan, terlebih dahulu dilakukan pembuatan surat izin pengabdian kepada pihak sekolah serta P2M IKIP Budi Utomo Malang.

\section{Persiapan sarana dan prasarana pelatihan}

Dalam pelaksaan pelatihan ESQ di SMP Al-Inayah Kecamatan Purwosari Kabupaten Pasuruan, dibutuhkan persiapan baik saranan dan prasarana yang mendukung proses pelatihan. Adapun sarana dan prasarana yang dibutuhkan meliputi, materi motivasi dan pelatihan ESQ yang dilengkapi dengan audio pendukung, materi motivasi, pemahaman pelatihan ESQ, LCD, Papan tulis, alat tulis, Laptop, sound, microphone, kelas atau gedung pelaksaan pelatihan ESQ.

\section{Pelaksanaan pelatihan}

Pelaksanaan pelatihan ESQ di SMP Al-Inayah Kecamatan Purwosari Kabupaten Pasuruan berjalan dengan baik dan lancar. Dimulai dengan pembukaan oleh pihak sekolah serta perwakilan tim pelatihan ESQ yang dilanjutkan dengan training motivasi terlebih dahulu yang diikuti oleh 
siswa kelas VII, VIII dan IX. Siswa siswi mengikuti dengan baik dan memperhatikan meski ada sedikit siswa siswi yang ramai. Hal ini tetap dapat diatasi hingga motivasi selesai dan berusaha menanamkan jiwa semangat belajar serta tidak mudah menyerah terutama bagi yang akan mengikuti ujian akhir nasional untuk mendapatkan nilai yang baik.

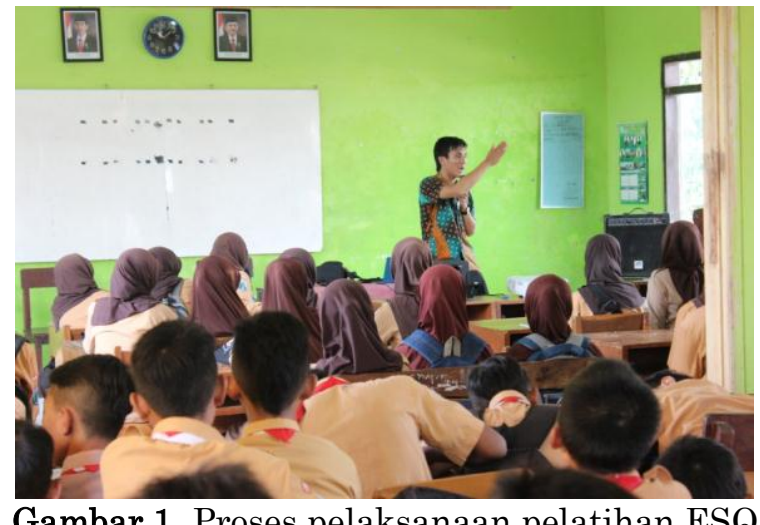

Gambar 1. Proses pelaksanaan pelatihan ESQ

Kegiatan selanjutnya adalah pelatihan ESQ yang menyentuh hati dan jiwa para peserta pelatihan. Bahkan sebagian besar dari mereka tidak kuasa menahan air mata yang mengalir. Mereka terbawa suasana pelatihan yang menyebabkan mereka mengingat kembali peran kedua orang tua, guru serta semua hal yang telah dilakukan selama ini bernilai baik atau belum. Akhir dari pelatihan ESQ ini membawa dampak positif bagi peserta yaitu lebih menyadari peran guru dan orang tua serta hal apa yang seharusnya mereka berikan untuk membalas budi. Hal ini dibuktikan dengan beberapa siswa mendatangi tim dan berbicara bahwa mereka sangat terbantu dan senang dengan adanya pelatihan ESQ ini. Mereka juga mengatakan adanya pelatihan ini memberikan kepercayaan diri kepada mereka bahwa mereka bisa dan mampu seperti siswa dari SMP negeri maupun favorit serta memberikan suatu pengalaman baru tentang pelatihan ESQ . Sejalan Dengan hasil penelitian Holida (2009) yang menjelaskan bahwa adanya training ESQ memberikan banyak manfaat seperti memahami makna hidup, menambah teman dan memperoleh suatu pengalaman baru.

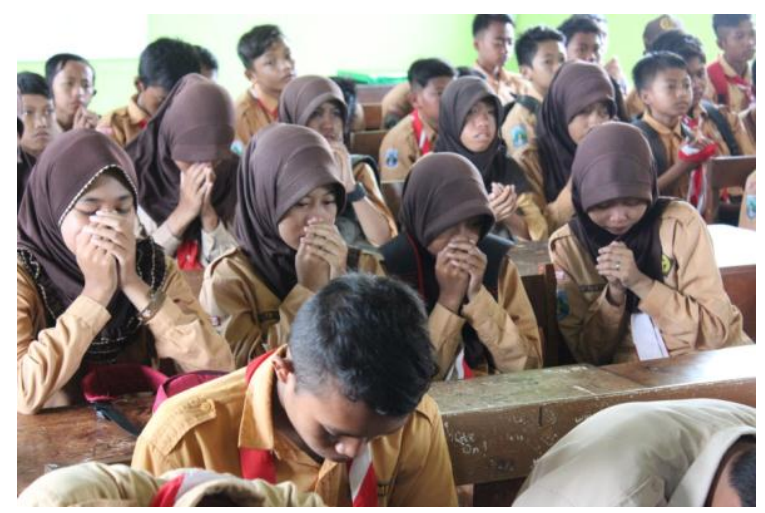

Gambar 2. Beberapa siswa tampak menangis dalam pelatihan

Berdasarkan hasil pelatihan yang diperoleh, menujukkan adanya hasil yang baik dari pelaksanaan pelatihan. Pembentukan karakter dan menciptakan suasana hati yang baik merupakan salah satu dampak positif dalam pelatihan ESQ. materi yang diberikan pada pelatihan ESQ terutama 
terkait materi character building serta proses perenungan yang mampu memberikan dampak positif tersebut. Holida (2009) menjelaskan proses perenungan dalam ESQ akan memberikan dampak positif kepada peserta untuk mengenali diri sendiri dan menumbuhkan suasana hati yang baik. Pelatihan ESQ ini dilaksanakan bertujuan untuk mampu memotivasi belajar siswa dan mampu menumbuhkan kemampuan yang dimiliki oleh siswa SMP Al-Inayah. Budi (2009) yang menyatakan pelatihan ESQ bertujuan untuk mampu membangkitkan kekuatan tersembunyi serta menumbuhkan segala potensi/kemampuan yang dimiliki seseorang. Lebih lanjut lagi Agustian (2001) menjelaskan melalui pelatihan ESQ seseorang dituntun untuk memberdayakan tujuh nilai dasar yang ada dalam dirinya, yaitu jujur, tanggung jawab, visioner, disiplin, kerjasama, adil dan peduli.

Pelatihan ESQ yang diberikan kepada siswa SMP Al-Inayah selain untuk menumbuhkan motivasi belajar juga diharapkan mampu meningkatkan hasil belajar maupun prestasi siswa. Hal ini dikarenakan adanya pelatihan ini yang mampu menumbuhkan motivasi belajar siswa sehingga siswa mampu mengontrol kecerdasan emosinya. Dengan siswa mampu mengontrol kecerdasan emosi secara tidak langsung akan memberikan dampak yang baik kepada hasil belajar maupun prestasi belajar siswa. Hartini (2004) menjelaskan bahwa adanya kecerdasan emosi akan memberikan manfaat terhadap segala aspek kehidupan seseorang, sedangkan kecerdasan intelektual hanya bermanfaat pada aspek pendidikan saja. Lebih lanjut lagi Kaddas, et.al (2009) menjelaskan bahwa salah satu manfaat pelatihan ESQ adalah mengoptimalkan kemampuan berpikir seseorang.

\section{SIMPULAN DAN SARAN}

Berdasarkan hasil pelaksanaan pengabdian diperoleh bahwa pelaksanaan pelatihan ESQ memberikan dampak positif kepada siswa SMP Al-Inayah Purwosari berupa peningkatan kepercayaan diri, pengalaman baru serta mampu meningkatkan motivasi belajar siswa. Melihat potensi tersebut maka perlu dilakukan kegiatan pelatihan serupa secara kontinyu untuk membantu menumbuhkan motivasi siswa.

\section{UCAPAN TERIMA KASIH}

Tim penulis mengucapkan terima kasih kepada Civitas akademik SMP Al-Inayah Purwosari yang telah bekerja sama dalam pelaksanaan pengabdian masyarakat ini dan juga kepada Pusat Penelitian dan Pengabdian Pada Masyarakat (P2M) IKIP Budi Utomo Malang yang membantu memfasilitasi kegiatan pengabdian ini sehingga terlaksana dengan baik.

\section{DAFTAR RUJUKAN}

Arifin, Z., \& Rahmawati, L. E. (2012). SNPT- and KKNI-Based Curriculum Organization. The Progressive \& Fun Education Seminar, (20), 212-219.

Erwinsyah, A. (2017). Manajemen kelas dalam meningkatkan efektifitas proses belajar mengajar. Manajemen Pendidikan Islam, 5(2), 87-105.

Kemenristekdikti, D. J. P. dan K. (2015). Paradigma Capaian Pembelajaran. In Direktorat Jendral Pembelajaran dan Kemahasiswaan Kementerian Riset, Teknologi, dan Pendidikan Tinggi Republik Indonesia. 
Mendari, A. S., \& Kewal, S. S. (2016). Motivasi Belajar Pada Mahasiswa. Jurnal Pendidikan Akuntansi Indonesia, $13(2)$. https://doi.org/10.21831/jpai.v13i2.10304

Nurhidayah, D. A. (2015). Pengaruh Motivasi Berprestasi Dan Gaya Belajar Terhadap Prestasi Belajar Siswa Pada Mata Pelajaran Matematika Smp. Jurnal Dimensi Pendidikan Dan Pembelajaran, 3(2), 13-24. https://doi.org/10.2426/dpp.v3i2.

Suryanti. (2016). Pengaruh Variasi Model Pembelajaran Dan Kemampuan Mengajar Guru Terhadap Motivasi. Sang Pencerah, 2(2), 529-534.

Zainal Arifin, A. P. D. (2015). Peran Guru Bimbingan Konseling dalam Membina Kecerdasan Emosional dan Spiritual Siswa Berkebutuhan Khusus. Nadwa, 9(1), 1. https://doi.org/10.21580/nw.2015.9.1.508 